Springer Link

Proceedings of the Future Technologies Conference (FTC) 2020, Volume 3

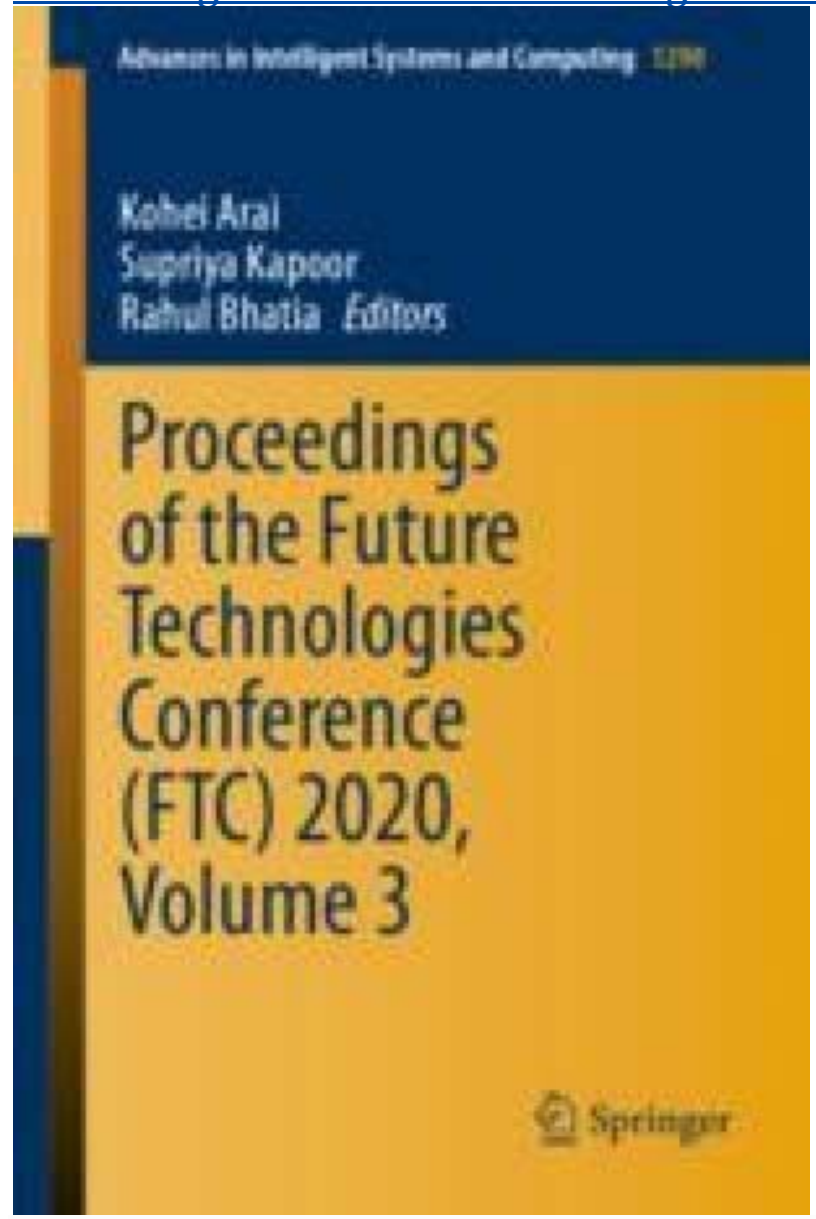

Proceedings of the Future Technologies Conference

FTC 2020: Proceedings of the Future Technologies Conference (FTC) 2020, Volume $\underline{3}$ pp 240-250| Cite as

\title{
Framework for an Integrated Ehealth Platform with Smart Diagnostic Engine for Improved Healthcare Access for Rural Dwellers
}

- Authors

- Authors and affiliations

- Francis E. Idachaba

- Ejura Mercy Idachaba 
Conference paper

First Online: 31 October 2020

\section{- 193Downloads}

Part of the Advances in Intelligent Systems and Computing book series (AISC, volume 1290)

\section{Abstract}

The healthcare challenges faced by rural dwellers in developing nations, especially those in the African continent include a lack of sufficient workforce, especially doctors, lack of healthcare facilities and access to the required medications. This paper presents a framework for the development of an integrated Ehealth platform which will provide the rural dwellers with access to high-quality medical personnel located in the urban areas. The unique advantages of this platform range from the inclusion of reputable pharmacies and medical diagnostic labs to minimize the risk of fake drugs and wrong diagnostic results coupled with integrated drug delivery and sample collection system which can be implemented using taxis, motorbikes or drones. The system also incorporates an Artificial Intelligence-based disease diagnostic engine which is designed to learn continuously from the patient/ doctor interactions and support the doctor in the patient diagnosis. This system presents a robust solution for providing rural dwellers with access to qualified medical service and also enable the doctors to prescribe high-quality drugs from reputable pharmacies close to the patient for the patient's use. Governments and donor agencies can utilize this platform to provide and pay for quality medical service to rural areas while at the same time, being able to track the spread of diseases.

\section{Keywords}

Ehealth Automated Disease Diagnosis Artificial Intelligence

This is a preview of subscription content, log in to check access.

\section{References}

1. 1.

Ojo, K.: The crisis in the distribution of health personnel in Nigeria. Health Policy

Plann. 5(1), 60- 65 (1990)CrossRefGoogle Scholar

2. 2 .

Kamien, M., Cameron, W.: Solving the shortage of general practitioners in remote and rural Australia: a Sisyphean task. Med. J . Aust. 185(11), 652- 653

(2006)CrossRefGoogle Scholar

3. 3 . 
How Digital Technologies Are Transforming Rural

Healthcare. https:// www.healthworkscollective.com/how-digital-technologies-aretransforming-rural-healthcare/

4. 4 .

Nyamtema, A., Mwakatundu, N., Dominic, S., Kasanga, M., J amadini, F., Maokola, K., Mawala, D., Abel, Z., Rumanyika, R., Nzabuhakwa, C., van Roosmalen, J .: Introducing eHealth strategies to enhance maternal and perinatal health care in rural Tanzania. Maternal Health, Neonatol. Perinatol. 3, 3 (2017). https:// doi.org/ 10.1186/s40748$\underline{017-0042-4}$

5. 5 .

Kombe, G., Chankova, S., Nguyen, H., Chipanta, D., Onoja, A., Ogungbemi, K., Taye, A.: Confronting HIV/ AIDS, TB, and Malaria: a situation analysis of human resources health in Nigeria: emerging challenges and opportunities, health Systems 20/20, USAID 2007Google Scholar

6. 6 .

Adeoye, I.A., Dairo, M.D., Adekunle, L.V., Adedokun, H.O., Makanjuola, J .: Investigation of the measles outbreak in a rural Nigeria community - The Aladura experience. Afr. J . Microbiol. Res. 4(5), 360- 366 (2010) Google Scholar

7. 7.

Kara, I.H., Ceylon, A., Acemoglu, H.: Measles epidemic in Turkey and developing countries: review of the literature. Middle East J. Family Med. 5(5) (2004)Google $\underline{\text { Scholar }}$

8. 8.

Spenser, F.J .: Epidemic Shigellosis in a rural area. Public Health Rep. 76(3), 219- 222 (1961) CrossRefGoogle Scholar

9. 9.

World Health Organization Media Center: African Trypanosomiasis or sleeping sickness. http:// www.who.int/ mediacentre/ factsheets/ fs259/ en/

10.10.

World Health Organization: WHO supports malaria epidemic prevention and control in Pakistan. www.who.int/ entity/ hac/ crises/pak/ releases/12october2010 
Prentice, A.M.: The emerging epidemic of obesity in developing countries. Int. J . Epidemiol. 35(1), 93- 99 (2005)MathSciNetCrossRefGoogle Scholar

Rural eHealth Program. http:// www.ehealth.nsw.gov.au/programs/clinical/rural

NSW RURAL HEALTH PLAN. Towards

2021. https:// www.health.nsw.gov.au/rural/Publications/rural-health-plan.pdf

14. 14.

Schrader, G., Bidargaddi, N., Harris, M., et al.: An eHealth intervention for patients in rural areas: preliminary findings from a pilot feasibility study. J MIR Res. Protoc. 3(2), e27 (2014). Published 2014 J un 12. https:// doi.org/ 10.2196/resprot.2861

15.15.

Barello, S., Triberti, S., Graffigna, G., et al.: eHealth for patient engagement: a systematic review. Front Psychol. (2016). 6:2013. Published 2016 J an 8. https:// doi.org/ 10.3389/ fpsyg.2015.02013

16. 16.

Salgado, T., Tavares, J ., Oliveira, T.: Drivers of mobile health acceptance and use from the patient perspective: survey study and quantitative model development. J MIR Mhealth Uhealth. 8(7), e17588. Published 2020 J ul 9. https:// doi.org/10.2196/17588

\section{Copyright information}

(C) Springer Nature Switzerland AG 2021

\section{About this paper}

CrossMark

\section{Cite this paper as:}

Idachaba F.E., Idachaba E.M. (2021) Framework for an Integrated Ehealth

Platform with Smart Diagnostic Engine for Improved Healthcare Access for

Rural Dwellers. In: Arai K., Kapoor S., Bhatia R. (eds) Proceedings of the Future Technologies Conference (FTC) 2020, Volume 3. FTC 2020. Advances in Intelligent Systems and Computing, vol 1290. Springer, Cham. https://doi.org/10.1007/978-3-030-63092-8_16

- First Online31 October 2020

- DOlhttps://doi.org/10.1007/978-3-030-63092-8_16

- Publisher NameSpringer, Cham 
- Print ISBN978-3-030-63091-1

- Online ISBN978-3-030-63092-8

- eBook Packages Intelligent Technologies and RoboticsIntelligent Technologies and Robotics (R0)

- Buy this book on publisher's site

- Reprints and Permissions

Log in to check access

$$
\begin{gathered}
\text { Buy eBook } \\
\text { EUR } 213.99 \\
\text { Buy paper (PDF) } \\
\text { EUR } 24.95
\end{gathered}
$$

Springer Nature

(C) 2020 Springer Nature Switzerland AG. Part of Springer Nature.

Not logged in Not affiliated 165.73.192.252 